\title{
Transcriptions and Orthography
}

omplications derive from the different ways in which names and terms are written and pronounced in Arabic, Dutch, English, Sanskrit, Javanese, Malay, Indonesian, Bugis and Makassarese as they were connected at some points in history. There is also the issue of overlap between language and terminology used in historical and contemporary contexts. For example, 'colonialism' is an analytical term for 'penjajahan', although both convey rather different meanings and applications. The word 'moderen' is used in local periodicals (such as Islam moderen) although 'the modern' means different things to different people.

This book uses the transcription system that is widely accepted. Some consonants are in their English forms, such as sh, rather than sy (for example, shari'ah rather than syariah, but Hasyim Asy'ari rather than Hashim Ash'ari). For consistency, the English spelling Sumatra is used rather than Sumatera and so is Java rather than Jawa. In other cases, consistency is difficult. Tjokroaminoto is used instead of Cakraaminata; Agus Salim is used rather than Agoes Salim; kemajuan instead of kemadjoewan; ummah instead of umat, oemat or umma; and Sulawesi instead of Celebes. But in a few places I have to keep the original, old spellings, such as Moehammadijah instead of Muhammadiyah. It should be noted, however, that one term may have different uses in different languages, such as adat. Adat (and its variations, such as ade and adat istiadat) is originally Arabic, but it has become local in different parts of the Indonesian-Malay world even before conversion to Islam. I use s for plural forms of Arabic concepts (fatwas, rather than fatawa).

The following system of letters are used in the text for denoting original languages. 

A. Arabic
B. Bugis
D. Dutch
I. Indonesian
J. Javanese
M. Malay
S. Sanskrit

I utilise the Qur'anic translations by Abdullah Yusuf Ali (1997), The Meaning of the Holy Qur'an, Beltsville, Maryland: Amana Publications, unless otherwise stated.

Many Arabic terms have become local and many Indonesian terms are Malay as well. Widely known names and words are spelled in their English forms, such as Ramadan and Muhammad. All dates follow Anno Domini $(\mathrm{AD})$ or Common Era (CE) unless noted otherwise. (AH is used for After Hijrah, the Islamic era.) I cite original terms and passages when they are particularly important to my argument. 